\title{
The Effects of Wastewater on The Chemical and Physical Properties of Fine-grained Soils
}

\author{
Nurdan Baykuş $^{1 *}$, Mehmet Karpuzcu ${ }^{2}$ \\ ${ }^{1 *}$ Kilis 7 Aralık University, Vocational School of Technical Sciences, Department of Construction, Vocational School of Technical Sciences, Kilis, Turkey, (ORCID: \\ 0000-0002-6199-3363),nurdanbaykus@kilis.edu.tr \\ ${ }^{2}$ Hasan Kalyoncu University, Faculty of Engineering, Department of Civil Engineering, Gaziantep, Turkey, (ORCID: 0000-0001-7488-0977), \\ mehmet.karpuzcu@hku.edu.tr
}

(First received 15 October 2021 and in final form 16 December 2021)

(DOI: 10.31590/ejosat.1010488)

ATIF/REFERENCE: Baykuş, N. \& Karpuzcu, M. (2021). The Effects of Wastewater on The Chemical and Physical Properties of Fine-grained Soils. European Journal of Science and Technology, (31), 771-775.

\begin{abstract}
The objective of this study was to evaluate the effects of different management and land use on soil chemical and physical properties as well as to validate the sensitivity of the soil to leachate. For this purpose, the effect of the wastewater discharged to the soil on the soil's properties taking advantage of the wastewater treatment capacity of the soil was investigated. In this study, different fine-grained soils named SA, SG, SK, and SU were placed in plexiglass pipes with a length of $100 \mathrm{~cm}$ and a diameter of $20 \mathrm{~cm}$ and fed with wastewater for 21 days with an uninterrupted flow. Soil samples were collected from pipes after 21 days and some parameters were evaluated the effect on soil structure. As a result, it was revealed that the existing chemical and physical properties of fine-grained soils were affected by wastewater. The $\mathrm{pH}$ values of the soils showed a slight tendency to increase after wastewater leachate, except for the SG soil. The $\mathrm{Na}$ and K contents of soils increased up to approximately $283 \%$ and $390 \%$, respectively. Additionally, it was calculated that the SAR of the soils increased by $118.18 \%-180.70 \%$. The EC value decreased by $8.77 \%$ in SA soil after wastewater leakage, while it increased by $189 \%$ in SG soil. While the $\mathrm{N}$ and $\mathrm{H}$ contents of soils decreased after the wastewater leachate, the $\mathrm{Mg}, \mathrm{Ca}, \mathrm{P}, \mathrm{Al}, \mathrm{Pb}, \mathrm{Zn}$, and $\mathrm{C}$ contents varied according to the soil type. As the fine grain percentage of the soils increased, their Na adsorption capacity increased $\left(\mathrm{r}^{2}=0.96\right)$.
\end{abstract}

Keywords: Fine-grained Soils, Soil Chemistry, Soil Filter, Wastewater Leakage.

\section{İnce Taneli Zeminlerin Kimyasal ve Fiziksel Özelliklerine Atık Suyun Etkileri}

$\ddot{O} \mathbf{z}$

$\mathrm{Bu}$ çalışmanın amacı, farklı yönetim ve arazi kullanımının, zeminlerin kimyasal ve fiziksel özellikleri üzerindeki etkilerini değerlendirmek ve ayrıca zeminin sızıntı suyuna karşı duyarlılığını doğrulamaktır. Bu amaçla, atık suyu arıtma kapasitesinden yararlanılarak, zemine deşarj edilen atık suların, zemin özellikleri üzerindeki etkisi incelenmiştir. Çalışmada, SA, SG, SK ve SU olarak adlandırılan farklı ince taneli zeminler, $100 \mathrm{~cm}$ uzunluğunda ve $20 \mathrm{~cm}$ çapında pleksi-glass borulara yerleştirildi ve kesintisiz akışla 21 gün boyunca atık su ile beslendi. 21 günün sonunda, zemin örnekleri toplandı ve zemin yapısına etkisini değerlendirmek için birtakım özellikleri incelendi. Sonuç olarak, ince taneli zeminlerin mevcut kimyasal ve fiziksel özelliklerinin atık sudan etkilendiği belirlendi. Atık su sızıntısından sonra, SG zemini hariç, zeminlerin $\mathrm{pH}$ değerleri hafif bir ölçüde artma eğilimdeydi. Zeminlerin Na ve K içeriğgi sırasıyla yaklaşık \%283 ve \%390'a kadar arttı. Ek olarak, zeminlerin SAR değerinde, \%118.18-\%180.70 oranında artış olduğu hesaplandı. EC değeri, SA zemininde \%8.77 oranında azalırken, SG zemininde \%189 oranında arttı. Atık su sızdırılan zeminlerin, N ve $\mathrm{H}$ içeriği azalırken, $\mathrm{Mg}, \mathrm{Ca}, \mathrm{P}, \mathrm{Al}, \mathrm{Pb}, \mathrm{Zn}$ ve $\mathrm{C}$ içerikleri, zemin tipine göre farklılık gösterdi. Zeminlerin ince dane yüzdesi arttıkça, Na absorpsiyon kapasiteleri artt1 $\left(\mathrm{r}^{2}=0.96\right)$.

Anahtar Kelimeler: İnce Taneli Zeminler, Zemin Kimyası, Zemin Filtresi, Atık Su Sızıntısı.

\footnotetext{
*Corresponding Author: nurdanbaykus@kilis.edu.tr
} 


\section{Introduction}

Nowadays, the treatment and recovery of wastewater are becoming increasingly important in terms of protecting water resources and reducing the burden on clean water resources [1]. Generally, wastewater treatment involves collecting the wastewater in a place that is transported by the central sewer system and treatment of wastewater according to its type. However, in some rural settlement areas without a central sewer system, network construction of the central sewer system can not possible and the harmless removal of wastewater can be provided by some natural treatment systems [2]. In these systems, the treatment capacity of the soil is used.

The treatment capacity of the soil can be roughly divided into three categories: filtration, adsorption, and decomposition [3]. Filtration provides the removal of pollutants such as turbidity, color, and suspended solids from the water by the flow of liquid (ie wastewater) through the soil pores. Adsorption can remove other pollutants retained by ion exchange [4]. And finally, decomposition can be defined as the microbial degradation of pollutants under aerobic or anaerobic conditions [3]. In general terms, it can be said that while the coarse particles in the soil perform the filtration process, the finer particles ensure the retention of pollutants by adsorption and some chemical reactions. Thus, pollutants substances in the dissolved state decompose and turn into less harmful substances or turn into insoluble substances and removed from the water by precipitation or adsorption. In this process, if the soil interacts with organic and inorganic pollutants, chemical, physical, mechanical and biological, etc. properties may change directly or indirectly [5]. Many research has been conducted on this subject in different disciplines $[2,21,22,23$, 24].

Chemical properties, composition, and reactions of the soil are fundamental to all soil processes that affect the use of soil [6]. It provides an explanation of the nature of chemical elements in the interaction of soil with pollutants.

The objective of this study was to evaluate the effects of the application of wastewater on soil chemical and physical properties in fine-grained soils as well as to validate the sensitivity of the soil to leachate. For this purpose, four different fine-grained soils were used as material. These soils were compressed in their natural density into plexiglass pipes of $100 \mathrm{~cm}$ length and $20 \mathrm{~cm}$ diameter and fed with wastewater in an uninterrupted flow for 21 days. When creating pipes, $20 \mathrm{~cm}$ of drainage material was placed on the lower and upper sections. Soil samples were collected from the pipes after 21 days. Then, analyzes were conducted to compare the effects of macro and microelements ( $\mathrm{Na}, \mathrm{Ca}, \mathrm{Mg}, \mathrm{K}$, $\mathrm{N}, \mathrm{P}, \mathrm{H}, \mathrm{Si}, \mathrm{Al}, \mathrm{Fe}, \mathrm{Pb}$, and $\mathrm{Zn}$ ) in the soil before and after leachate. Scanning electron microscope (SEM) imaging was examined to obtain information about the structure of soil particles. Additionally, a parameter such as the sodium absorption ratio (SAR) was derived from the data obtained.

\section{Material and Method}

\subsection{Soil and Wastewater Samples}

Soil samples used in this study were collected separately from four different provinces in the Southeast Anatolian Region/Turkey. In addition, it was taken from a depth of 150-200 $\mathrm{cm}$ by removing the organic layer. These samples (named SA, SG,
SK, and SU) were transported to a wastewater treatment facility in Gaziantep province to conduct experimental studies. Sieve and hydrometer analyses by ASTM D422-63 and ASTM D7928-17 were performed to determine the grain size distribution of the soil samples. Grain size distribution analysis showed that the fine grain percentages passing No.200 $(0.075 \mathrm{~mm})$ sieve were $65.49 \%$, $72.64 \%, 58.65 \%$, and $86.32 \%$ for soil samples SA, SG, SK, and SU, respectively (Fig. 1).

The wastewater used in the study was obtained from the raw influent wastewater of the facility. The average water characteristics of the raw influent wastewater of the facility are given in Table 1. The water was first pumped into a septic tank, and then pipes formed from four different fine-grained soils were fed for 21 days uninterrupted at an average flow rate of 18 day/L. Soil samples for determining chemical properties were collected from emptied pipes at the end of 21 days. The samples were airdried at room temperature, lightly crushed, and passed through a $0.425 \mathrm{~mm}$ sieve. The fine soil fraction $(0.425 \mathrm{~mm})$ was retained for chemical and physical analyses.

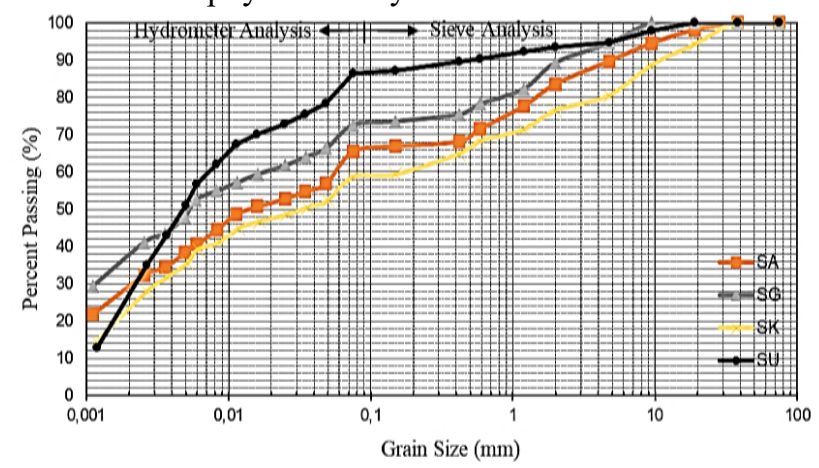

Figure 1. Grain size distribution of fine-grained soils.

Table 1. Average some properties of facility influent wastewater during the experimental study.

\begin{tabular}{c|c}
\hline Parameters & Values \\
\hline $\mathrm{pH}$ & 7.685 \\
\hline Conductivity $(\mu \mathrm{S} / \mathrm{cm})$ & 1552.85 \\
\hline Chemical Oxygen Demand $(\mathrm{mg} / \mathrm{L})$ & 325.937 \\
\hline Suspended Solids $(\mathrm{mg} / \mathrm{L})$ & 330.565 \\
\hline Total N (mg/L) & 52.37 \\
\hline Total P $(\mathrm{mg} / \mathrm{L})$ & 4.375 \\
\hline $\mathrm{Ca}(\mathrm{mg} / \mathrm{L})$ & 100.325 \\
\hline $\mathrm{Mg}(\mathrm{mg} / \mathrm{L})$ & 24.498 \\
\hline $\mathrm{Na}(\mathrm{mg} / \mathrm{L})$ & 76.755 \\
\hline $\mathrm{K}(\mathrm{mg} / \mathrm{L})$ & 40.738 \\
\hline
\end{tabular}

\subsection{Chemical and Physical Analyses}

In this study, the chemical and physical properties of the soils were analyzed separately for each soil before and after wastewater was given to soil pipes and the results were compared. Soil samples were submitted to the University of Harran Application and Research Center for Science and Technology for the following analyses: sodium $(\mathrm{Na})$, magnesium $(\mathrm{Mg})$, calcium $(\mathrm{Ca})$, potassium $(\mathrm{K})$, nitrogen $(\mathrm{N})$, phosphate $(\mathrm{P})$, hydrogen $(\mathrm{H})$, iron $(\mathrm{Fe})$, aluminum $(\mathrm{Al})$, lead $(\mathrm{Pb})$, zinc $(\mathrm{Zn})$ and carbon $(\mathrm{C})$. Analyses of these elements were measured using an Inductively Coupled Plasma Optical Emission Spectrometer (ICP-OES). Soil 
pH was measured with a HI221-pH meter in a solution prepared ratio of $1 / 2$ ( 1 soil $=2$ distilled water $)[7,8,26]$. The electrical conductivity (EC) was also determined using the 4520Conductivity meter in the same solution. The SEM imaging of soils at $100 \mu \mathrm{m}$ diameter and 100x magnification was conducted by Model-ZEISS/EVO LS10. Moreover, the sodium adsorption ratio (SAR) of fine-grained soils was calculated from the following equation based on the content of exchangeable cations $\mathrm{Na}, \mathrm{Mg}$, and $\mathrm{Ca}[9,10]$.

$\mathrm{SAR}=\frac{\mathrm{Na}+}{\sqrt{\frac{[\mathrm{Ca}+2]+[\mathrm{Mg}+2]}{2}}}$

\section{Results and Discussion}

Many of the current methods used to assess the effects of treatment on soil chemical properties have focused on soil chemical properties such as the content of C, N, P, and K elements $[8,25]$. However, this situation may be limited in detecting shortterm changes in the soil structure. Therefore, soil chemical elements were investigated more comprehensively in this study. The results of all analyzes of the soils are presented in Tables 2 and 3 .

Table 2. Chemical and physical properties of fine-grained soils.

\begin{tabular}{|c|c|c|c|c|}
\hline \multirow{2}{*}{ Parameters } & \multicolumn{4}{|c|}{ Soil Type } \\
\hline & SA & SG & SK & SU \\
\hline $\mathrm{pH}$ & 7.97 & 7.98 & 7.88 & 8.12 \\
\hline $\mathrm{EC}(\mu \mathrm{S} / \mathrm{cm})$ & 308 & 376 & 288 & 314 \\
\hline $\mathrm{Na}(\mathrm{mg} / \mathrm{kg})$ & 3.261 & 1.929 & 2.194 & 1.538 \\
\hline $\mathrm{Mg}(\mathrm{mg} / \mathrm{kg})$ & 171.1 & 72.72 & 97.59 & 59.46 \\
\hline $\mathrm{Ca}(\mathrm{mg} / \mathrm{kg})$ & 2192 & 2211 & 3119 & 944.2 \\
\hline $\mathrm{K}(\mathrm{mg} / \mathrm{kg})$ & 4.894 & 13.00 & 8.106 & 9.548 \\
\hline $\mathrm{P}(\mathrm{mg} / \mathrm{kg})$ & 359.6 & 50.19 & 97.83 & 32.95 \\
\hline $\mathrm{Fe}(\mathrm{mg} / \mathrm{kg})$ & 625.0 & 328.0 & 319.9 & 120.9 \\
\hline $\mathrm{Al}(\mathrm{mg} / \mathrm{kg})$ & 245.4 & 224.0 & 159.1 & 70.68 \\
\hline $\mathrm{Pb}(\mathrm{mg} / \mathrm{kg})$ & 0.163 & 0.289 & 0.080 & 0.121 \\
\hline $\mathrm{Zn}(\mathrm{mg} / \mathrm{kg})$ & 0.711 & 0.465 & 0.661 & 0.264 \\
\hline $\mathrm{N}(\%)$ & 0.20879817 & 0.16231136 & 0 & 0 \\
\hline H (\%) & 1.12872493 & 1.16791511 & 1.11512291 & 0.803222 \\
\hline $\mathrm{C}(\%)$ & 3.02648735 & 2.829049349 & 3.577930212 & 0.491614372 \\
\hline SAR (\%) & 9.50 & 5.70 & 5.50 & 6.90 \\
\hline
\end{tabular}

Table 3. Chemical and physical properties of fine-grained soils after wastewater leakage.

\begin{tabular}{|c|c|c|c|c|}
\hline \multirow{2}{*}{ Parameters } & \multicolumn{4}{|c|}{ Soil Type } \\
\hline & SA & SG & SK & SU \\
\hline $\mathrm{pH}$ & 8.02 & 7.76 & 8.22 & 8.22 \\
\hline $\mathrm{EC}(\mu \mathrm{S} / \mathrm{cm})$ & 281 & 1087 & 619 & 240 \\
\hline $\mathrm{Na}(\mathrm{mg} / \mathrm{kg})$ & 7.319 & 5.967 & 4.664 & 5.901 \\
\hline $\mathrm{Mg}(\mathrm{mg} / \mathrm{kg})$ & 142.6 & 91.07 & 100.8 & 152.9 \\
\hline $\mathrm{Ca}(\mathrm{mg} / \mathrm{kg})$ & 1826 & 2689 & 2893 & 2441 \\
\hline $\mathrm{K}(\mathrm{mg} / \mathrm{kg})$ & 24.07 & 24.03 & 8.956 & 29.37 \\
\hline $\mathrm{P}(\mathrm{mg} / \mathrm{kg})$ & 74.21 & 61.12 & 88.34 & 72.93 \\
\hline $\mathrm{Fe}(\mathrm{mg} / \mathrm{kg})$ & $<0.05$ & 373.0 & 309.1 & 376.5 \\
\hline $\mathrm{Al}(\mathrm{mg} / \mathrm{kg})$ & $<0.05$ & 247.8 & 130.0 & 212.5 \\
\hline $\mathrm{Pb}(\mathrm{mg} / \mathrm{kg})$ & 0.120 & 0.351 & 0.076 & 0.382 \\
\hline $\mathrm{Zn}(\mathrm{mg} / \mathrm{kg})$ & 0.531 & 0.772 & 0.676 & 0.775 \\
\hline $\mathrm{N}(\%)$ & 0.153939202 & 0.160495475 & 0 & 0 \\
\hline $\mathrm{H}(\%)$ & 0.73824626 & 1.11031353 & 1.04763496 & 0.60363293 \\
\hline $\mathrm{C}(\%)$ & 2.932234526 & 3.326600552 & 4.142601013 & 2.248875141 \\
\hline SAR (\%) & 23.0 & 16.0 & 12.0 & 16.0 \\
\hline
\end{tabular}

After the wastewater leakage, the $\mathrm{pH}$ value decreased in the SG soil, while it increased in other soils. The most obvious increase occurred in SK soil with approximately $4.4 \%$. Researchers have stated that there may be a small amount increase in the $\mathrm{pH}$ values after leakage of soils with slightly alkaline properties [11]. The EC values differed according to soil type. After wastewater leakage, the EC value of SA and SU soils decreased by $8.77 \%$ and $23.57 \%$, respectively, while SG and SK increased by $189 \%$ and $115 \%$, respectively. Previous studies have shown that the salinity value of the filtration fluid or SAR is related to the EC of the soil [12]. However, soil structure and formation are mainly important. Moreover, the solubility of salts and minerals other than $\mathrm{Na}$ is also important [26].
When the Na element content was examined, it was observed that there was an increase in all soil types between $112.58 \%$ and $283.68 \%$. Moreover, the SAR values of the soils increased in the range of $118.18 \%-180.70 \%$, depending on both the increase in $\mathrm{Na}$ contents and the decrease in $\mathrm{Ca}$ or $\mathrm{Mg}$ content. When the $\mathrm{Na}$ or SAR value absorbed in the soil exceeds $10-15 \%$, decomposition or swelling of clays can lead to problems such as a decrease in soil pore size due to the fragmentation of coarse grains and thus a decrease in soil permeability $[12,13,14]$. Generally, it has been recorded that the clay content is high in soils with such problems [29]. Because the main sorbents that can exchange ions in the soil are clay minerals and organic substances [30]. Moreover, the $\mathrm{Ca}$ content has a flocculation effect in the soil whereas $\mathrm{Mg}$ content has an inverse effect. So, increasing the $\mathrm{Ca} / \mathrm{Mg}$ ratio can improve 
soil structure and aggregate stability [27]. But, results from this study showed that $\mathrm{Na}$ accumulated more than $\mathrm{Ca}$ in soil structure. Also, this accumulation was observed to be correlated with the fine grain ratios of the soils (Fig. 2). For this reason, the soil structure is likely to disintegrate or decompose. It seems that support is also the SEM images of soils before and after wastewater leakage (Fig. 3, 4, 5, and 6).

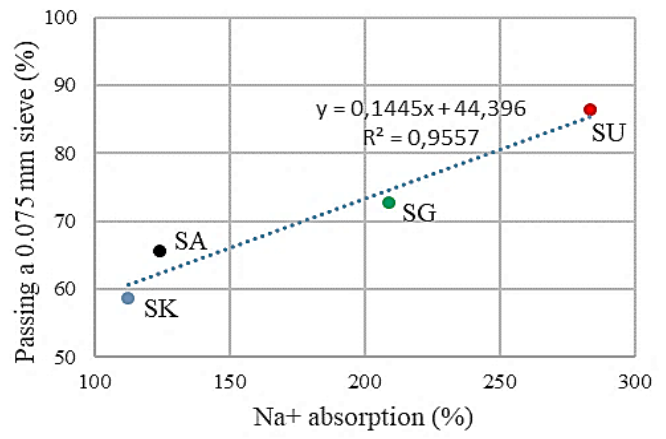

\section{Figure 2. Grain size and $\mathrm{Na}^{+}$absorption percentage of soils.}

Previous studies have reported that monovalent cations (ie. $\mathrm{Na}^{+}$and $\mathrm{K}^{+}$) in the soils also affected soil stability and bulk density $[15,27]$. When Tables 2 and 3 were examined, the $\mathrm{K}$ content of all soils increased after wastewater leakage. The highest increase occurred in the $\mathrm{K}$ content of the SA soil at a rate of approximately $390.0 \%$.
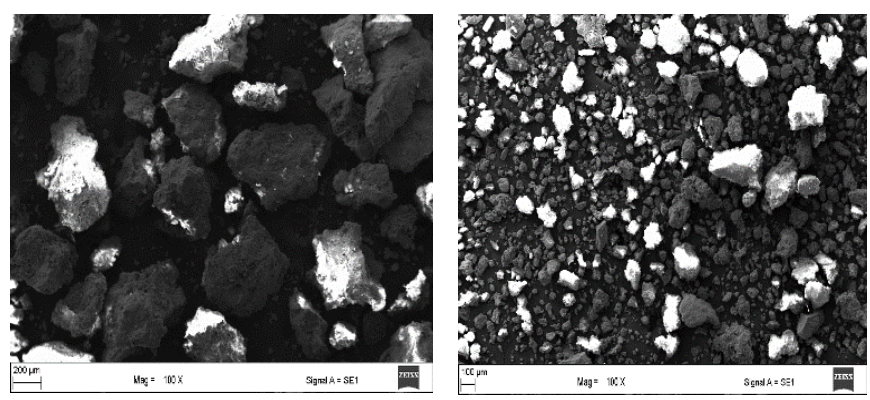

Figure 3. SEM image of SA soil.
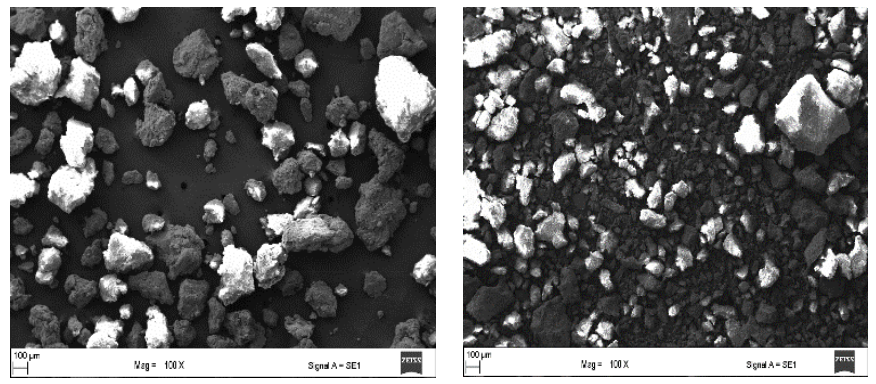

Figure 4. SEM image of SG soil.
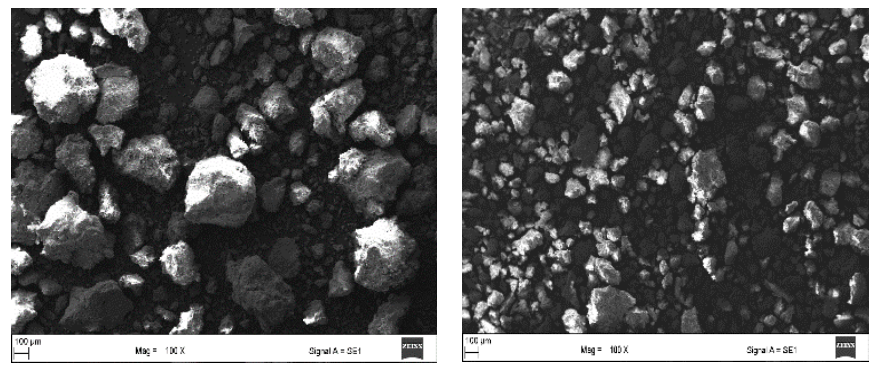

Figure 5. SEM image of SK soil.
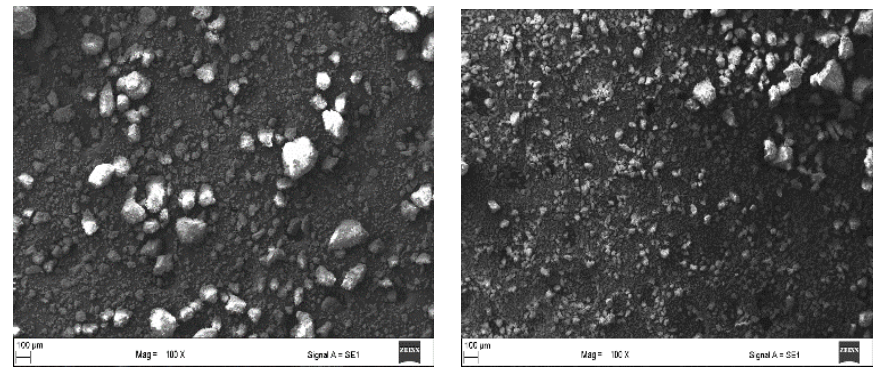

Figure 6. SEM image of SU soil

* Images (Fig. 3, 4, 5, and 6) represent the before (left) and after (right) wastewater leakage.

After the wastewater leakage, the P content in SA and SK soil decreased by $79.40 \%$ and $9.70 \%$, respectively, while it increased in other soils. As for the $\mathrm{N}$ content, it decreased by $26.0 \%$ and $1.12 \%$ in SA and SG soils, respectively. The $\mathrm{N}$ content was not found in the SK and SU soils. The H content of the soils decreased somewhat after the wastewater leakage. The $\mathrm{C}$ content of the soils increased, except for SA. The C content in soils can be stated as an important mechanism in the complexation of soil or clay minerals [16]. Also, it can be expressed that it is important in terms of microbial activity [17].

When the elements in the metal group were examined, the content of $\mathrm{Fe}$ and $\mathrm{Al}$ decreased significantly in the SA soil and even depleted. The amounts of these elements increased in SG and SU soils but decreased slightly in SK soil. While the contents of $\mathrm{Pb}$ and $\mathrm{Zn}$ elements increased slightly in SG and SU soils, they decreased in SA soils. On the other hand, there was no significant change in SK soil. Previous studies have shown that treated wastewater use or continuous application of municipal wastewater can increase the existing heavy metal content in soil $[18,19]$. In other studies, it has been stated that wastewater treatment or irrigation did not have a significant effect on the heavy metal content in soil [20, 27, 28].

\section{Conclusions and Recommendations}

Soil chemical properties are important in contributing to soil use processes, controlling the status and activities of certain microbial communities, and characterizing soil quality. In this study, the effects of land filtration methods used for wastewater disposal and treatment in rural areas on the chemical and physical properties of different soils were investigated. As a result of this study, the effect of wastewater on the existing properties of finegrained soils was revealed.

After the wastewater leakage, the $\mathrm{pH}$ of the soils tended to increase slightly, except for the SG soil. While the EC value decreased by $8.77 \%$ in SA soil, it increased by $189 \%$ in SG soil. After wastewater leakage, $\mathrm{Na}$ and $\mathrm{K}$ contents of all soils were found to increase. In addition, it was calculated that the SAR value of the soils increased by $118.18 \%-180.70 \%$. While the $\mathrm{N}$ and $\mathrm{H}$ contents of the soils after wastewater leakage decreased, the contents of $\mathrm{Mg}, \mathrm{Ca}, \mathrm{P}, \mathrm{Al}, \mathrm{Pb}, \mathrm{Zn}$, and $\mathrm{C}$ varied according to the soil type. It was found that as the fine grain percentage of the soils increased, the $\mathrm{Na}$ absorption capacity increased $\left(\mathrm{r}^{2}=0.96\right)$.

The accumulated effect of organic and inorganic liquids on soil structure with a well-designed field experiment can be monitored and evaluated over a long period. As a result of 
different land use and management, the chemical and physical properties of soils may be affected.

\section{References}

[1] Bixio, D., Thoeye, C., De Koning, J., Joksimovic, D., Savic, D., Wintgens, T., \& Melin, T. (2006). Wastewater reuse in Europe. Desalination, 187(1-3), 89-101.

[2] Baykuş, N. (2021). Treatment of wastewater by infiltration and its effect on the engineering properties of natural soils. Department of Civil Engineering, Graduate School of Natural and Applied Sciences, Hasan Kalyoncu University, Ph.D. Thesis.

[3] Wang, X. H., Zhang, Y., \& Huang, C. H. (2014). Experimental study on the treatment of sewage by soil. In Applied Mechanics and Materials (Vol. 464, pp. 179-183). Trans Tech Publications Ltd.

[4] Cheremisinoff, N. P. (2001). Handbook of water and wastewater treatment technologies. Butterworth-Heinemann. ISBN: 0-7506-7498-9.

[5] Mohamed, O. M. A., and Antia, E. H. (1998). Geoenvironmental Engineering, Vol.82, 1st Edition, Imprint: Elsevier Science, ISBN: 9780080532448, 706.

[6] Sparks, D. L. (2019). Fundamentals of soil chemistry. Encyclopedia of Water: Science, Technology, and Society, 1-11.

[7] Acir, N. \& Günal, H. (2019). Toprak katyon değişimin kapasitesi tahmininde pedotransfer fonksiyonlarının kullanımı. Ispec Uluslararası Tarım ve Kırsal Kalkınma Kongresi, 10-12 Haziran 2019, 437-443.

[8] Odlare, M., Pell, M., \& Svensson, K. (2008). Changes in soil chemical and microbiological properties during 4 years of application of various organic residues. Waste management, 28(7), 1246-1253.

[9] Suarez, L. D. and Gonzalez-Rubio, A. (2017). Effects of the dissolved organic carbon of treated municipal wastewater on soil infiltration as related to sodium adsorption ratio and $\mathrm{pH}$. Soil Science Society of America Journal, (2017)81:602-611, DOI:10.2136/sssaj2016.09.0310.

[10]Richards, L. A. (Ed.) (1954). Diagnosis and improvement of saline and alkali soils, Agriculture Handbook No. 60, U.S. Department of Agriculture, Washington, D.C.

[11]Husson, O., Brunet, A., Babre, D., Charpentier, H., Durand, M., \& Sarthou, J. P. (2018). Conservation agriculture systems alter the electrical characteristics (Eh, $\mathrm{pH}$, and $\mathrm{EC}$ ) of four soil types in France. Soil and Tillage Research, 176, 57-68.

[12]Temizel, K. E., \& Sedat, T. O. K. (2019). Farklı sodyum adsorbsiyon oranı değerlerine sahip sulama sularının bazı toprak özelliklerine etkisi. Journal of the Institute of Science and Technology, 9(3), 1729-1736.

[13]Läuchli, A. and Epstein, E. (1990). Plant responses to saline and sodic conditions. Agricultural salinity assessment and management, 71, 113-137.

[14]Jnad, I. (2000). Characterizing soil hydraulic properties in the drainfield of a subsurface drip distribution system. Texas A\&M University, Doctor of Philosophy Thesis, Civil Engineering, December 2000.

[15]Tejada, M., \& Gonzalez, J. L. (2005). Beet vinasse applied to wheat under dryland conditions affects soil properties and yield. European Journal of Agronomy, 23(4), 336-347.

[16]Sparks, D. L. (2019). Fundamentals of soil chemistry. Encyclopedia of Water: Science, Technology, and Society, 1-11.
[17]Rezaei, S. A., \& Gilkes, R. J. (2005). The effects of landscape attributes and plant community on soil chemical properties in rangelands. Geoderma, 125(1-2), 167-176.

[18]Abd-Elwahed, M. S. (2018). Influence of long-term wastewater irrigation on soil quality and its spatial distribution. Annals of Agricultural Sciences, 63(2), 191-199.

[19]Khaskhoussy, K., Kahlaoui, B., Nefzi, B. M., Jozdan, O., Dakheel, A., \& Hachicha, M. (2015). Effect of treated wastewater irrigation on heavy metals distribution in a Tunisian soil. Engineering, Technology \& Applied Science Research, 5(3), 805-810.

[20]Galavi, M., Jalali, A., Ramroodi, M., Mousavi, S. R., \& Galavi, H. (2010). Effects of treated municipal wastewater on soil chemical properties and heavy metal uptake by sorghum (Sorghum bicolor L.). Journal of Agricultural Science, 2(3), 235.

[21]Oluremi, J. R., Adedokun, S. I., Olaoye, R. A., Ajamu, S. O., \& Eng, M. (2012). Assessment of cassava wastewater on the geotechnical properties of lateritic soil. Pacific Journal of Science and Technology, 13(1), 631-639.

[22]Abedi-Koupai, J., Mostafazadeh-Fard, B., Afyuni, M., \& Bagheri, M. R. (2006). Effect of treated wastewater on soil chemical and physical properties in an arid region. Plant Soil and Environment, 52(8), 335.

[23]Karpuzcu, M., Baykuş, N., \& Yurtsever, A. (2020). An experimental study on treatment of domestic wastewater by natural soil. Engineering Sciences, 15(4), 196-208.

[24]Irfan, M., Chen, Y., Ali, M., Abrar, M., Qadri, A., and Bhutta, O. (2018). Geotechnical properties of effluent-contaminated cohesive soils and their stabilization using industrial byproducts. Processes, 6(2018), 203, DOİ:10.3390/pr6100203.

[25]Asik, B. B., Aydinalp, C., Katkat, A. V., \& Sagban, F. O. T. (2015). Effect of the application of various wastewater sludges on the properties of sandy soil. Environmental monitoring and assessment, 187(2), 1-11.

[26]Sparks, D. L., Page, A. L., Helmke, P. A., Loeppert, R. H., \& Rhoades, J. D. (1996). Salinity: Electrical Conductivity and Total Dissolved Solids. Methods of Soil Analysis Part 3Chemical Methods.

[27]Hasan, H., Battikhi, A., \& Qrunfleh, M. (2014). Impacts of treated wastewater reuse on some soil properties and production of Gladiolus communis. Journal of Horticulture, $1-9$.

[28]Mohammad Rusan, M. J., Hinnawi, S., \& Rousan, L. (2007). Long term effect of wastewater irrigation of forage crops on soil and plant quality parameters. Desalination, 215(1-3), 143-152.

[29]Dawes, L., \& Goonetilleke, A. (2003). An investigation into the role of site and soil characteristics in onsite sewage treatment. Environmental Geology, 44(4), 467-477.

[30]Thompson, A., \& Goyne, K. W. (2012). Introduction to the sorption of chemical constituents in soils. Nature Education Knowledge, 4(4), 7. 